\title{
Shading Levels and Substrates Affect Morphophysiological Responses and Quality of Anadenanthera peregrina (L.) Speg Seedlings
}

\author{
Cleberton Correia Santos ${ }^{1}$ (D) 0000-0001-6741-2622
}

Higor Périkles Guedes Jorge ${ }^{1}$ (D) 0000-0002-4978-784X

Luiz Gabriel Fernandes Dias ${ }^{1}$ (D) 0000-0003-3867-103X

Maria do Carmo Vieira ${ }^{1}$ (D) 0000-0001-7047-3848

\begin{abstract}
It is essential to know the ecological tolerance of Anadenanthera peregrina (L.) Speg seedlings regarding the light and edaphic conditions. The aim of this study was to evaluate the effect of substrates and shading levels on the emergence and quality of $A$. peregrina seedlings. The seeding was done in two substrates: 100\% Dystroferric Red Latosol (DRL) and DRL + commercial substrate $(1: 1, \mathrm{v} / \mathrm{v})$. The species were kept under four shading levels: $0 \%$ (direct sunlight), 30\%, $50 \%$ and $70 \%$. The highest speed and shortest emergence time of $A$. peregrina occurred in DRL. The highest growth characteristics of aerial part, xylopodium and roots occurred under direct sunlight and DRL. The productions of fresh and dried masses of different vegetative organs, physiological and Dickson quality index were higher in DRL and direct sunlight. The $A$. peregrina seedlings in $100 \%$ of DRL and direct sunlight showed more viable morphophysiological and quality indicators for their production.
\end{abstract}

Keywords: cerrado biome, light, ecological tolerance, reserve structure, xylopodium.

\section{Introduction and objective}

Among the native species found in the Brazilian Cerrado, it can be noted that the species Anadenanthera peregrina (L.) Speg., also known as "Angico preto", belongs to the Fabaceae family and it has biological nitrogen fixation potential and it is a significant option to be inserted in areas for forest recomposition (Souza et al., 2012) or agroforestry systems. The wood can be used for charcoal, firewood, furniture, flooring and construction, as it has high density $\left(1.08 \mathrm{~g} / \mathrm{cm}^{3}\right)$, strength and durability, as well as smooth and glossy surface with high decorative value (Mori et al., 2003; Monteiro et al., 2006).

According to the medicinal point of view of this species, it is used to treat respiratory, pulmonary and diarrhea infections (Mota et al., 2017a). Regarding the $A$. peregrina importance and its risk of reduction and/or extinction of native forests due to inappropriate collection practices or anthropogenic actions of vegetal suppression, its ex situ cultivation becomes necessary, especially owing to the information about the seedling productions.
Among the abiotic factors, the light availability is one of the environmental conditions that influence the establishment of tree species in the Cerrado physiognomies (Pinheiro \& Monteiro, 2010). This way, the exposure of plants to different light conditions may vary depending on the species and its successional degree. The species may present adaptive mechanisms based on adjustments of their photosynthetic apparatus, in order to use light more efficiently (Ruban, 2015; Carvalho \& Castilho, 2018).

Thus, it is important to know the tolerance and capacity of seedlings from native Cerrado species, especially those of A. peregrina, in response to light gradients, aiming to direct the insertion area to be transplanted considering the growth indicators and the quality of seedlings that ensure their performance under different environmental restrictions.

Another practice of plant nursery should be analyzed aiming the decision to ensure seedling quality standards for the substrate. The substrate that will be used must present good chemical, physical and microbiological attributes, in order to meet the nutritional requirements of the species and provide good growth conditions (Fonseca \& Scott, 2018; Ceccagno et al., 2019) of

\footnotetext{
Universidade Federal da Grande Dourados (UFGD), Faculdade de Ciências Agrárias (FCA), Dourados, MS, Brasil
} 
the different vegetative organs. Some species respond positively to substrates with higher fertility (Carlos et al., 2018) while others present better development with acid $\mathrm{pH}$, aluminum presence and lower organic matter and nutrients (Gross et al., 2004; Souza et al., 2016).

In the scientific field, it could be found several studies associated with different substrates regarding the growth and quality of many native tree species in Cerrado biome, such as: Tocoyena formosa (Cham. \& Schltdl.) K. Schum (Bonamigo et al., 2016); Alibertia sessilis (Vell.) K. Schum (Mota et al., 2017b); Eugenia dysenterica DC. (Dornelles et al., 2018) and Copaifera langsdorffii Desf. (Fonseca \& Scotti, 2018).

For the genus Anadenanthera, academics works were found with the species A. columbrina (Vell.). Brenan (Scheer et al., 2012) and $A$. macrocarpa (Benth.) Brenan (Uliana et al., 2014), but not with $A$. peregrina. The hypotheses seeking to answer the following questions were tested: i) May $A$. peregrina tolerate different shading levels without changing the quality of the seedlings? ii) What is the preferred substrate and fertility of the species? iii) What is the best area for transplantation considering its production indicators?

In relation to those questions, the aim of this study was to evaluate the effect of different shading levels and substrates on emergence, morphophysiological response and quality of A. peregrina seedling.

\section{Material and methods}

\subsection{General conditions and seed collected}

The experiment was developed in July 2018 until December 2018 at the Faculty of Agrarian Sciences (22011'43.7”S and $54{ }^{\circ} 56^{\prime} 08.5$ "W, $452 \mathrm{~m}$ ) at the Universidade Federal da Grande Dourados (UFGD), in the city of Dourados, and in the state of Mato Grosso do Sul (MS), Brazil. To perform the work, the species was identified and a voucher was deposited in the Dourados, State of MS (DDMS) Herbarium of UFGD, under the registration no. 5416. In July, the fruits from ten matrices of A. peregrina were randomly collected from the remaining Cerrado area (SISGEN Access Register No. A9CDAAE), located at the Santa Madalena Farm (1807'03”S and 54²5'07”W, 452 m).

\subsection{Factors and experimental design}

After the fruits were used, seeding was immediately performed at $\pm 1.0 \mathrm{~cm}$ depth in $290 \mathrm{~cm}^{3}$ polyethylene tubes filled with two substrates: S1) $100 \%$ of Dystroferric Red Latosol (DRL) with clay texture (Santos et al., 2018); and S2) DRL + commercial substrate - Tropstrato ${ }^{\circledR}(1: 1, \mathrm{v} / \mathrm{v})$, packaged under four shading levels: $0 \%$ (direct sunlight), 30\%, 50\% and $70 \%$. The experimental arrangement was performed in a $2 \times 4$ factorial scheme, in a randomized block design with three replications, and each experimental unit consisted of 27 sub samples.

The commercial substrate (Tropstrato ${ }^{\circledR}$ ) used to prepare S2 substrate was composed of pine bark, peat, expanded vermiculite, potassium nitrate and simple superphosphate. The effects of shading on species were obtained using black colored screens with different light retention levels. During the experimental period, the crop treatments were consisted of daily irrigation, once a day, using micro-sprinklers, maintaining $70 \%$ of water retention capacity on substrate according to Souza et al. (2000), and spontaneous weeding when necessary. The chemical attributes of the substrates at the end of cycle of seedling production (Table 1) were determined according to Silva (2009) methodology.

\subsection{Emergence indicators}

The hypocotyl began to straighten at seven days after seeding, while the epicotyl and cotyledons began at ten days (Figure 1B). After this period, between the interval of two days,

Table 1. Chemical attributes of substrates at the end cycle of $A$. peregrina seedling production in different substrates and shading levels.

\begin{tabular}{|c|c|c|c|c|c|c|c|c|}
\hline \multirow{2}{*}{ Attributes } & \multicolumn{2}{|c|}{$0 \%$} & \multicolumn{2}{|c|}{$30 \%$} & \multicolumn{2}{|c|}{$50 \%$} & \multicolumn{2}{|c|}{$70 \%$} \\
\hline & S1 & S2 & S1 & S2 & S1 & S2 & S1 & S2 \\
\hline $\mathrm{pH} \mathrm{H} \mathrm{H}_{2} \mathrm{O}$ & 5.03 & 6.54 & 5.41 & 6.45 & 5.73 & 6.53 & 5.86 & 6.45 \\
\hline $\mathrm{P}\left(\mathrm{mg} \mathrm{dm}^{-3}\right)$ & 5.61 & 73.66 & 3.73 & 96.25 & 5.88 & 93.03 & 5.34 & 59.14 \\
\hline $\mathrm{K}\left(\mathrm{cmol}_{\mathrm{c}} \mathrm{dm}^{3}\right)$ & 0.23 & 0.62 & 0.15 & 0.66 & 0.20 & 0.60 & 0.17 & 0.59 \\
\hline $\mathrm{Ca}\left(\mathrm{cmol}_{\mathrm{c}} \mathrm{dm}^{3}\right)$ & 2.95 & 10.07 & 2.65 & 10.41 & 2.93 & 10.04 & 2.82 & 8.01 \\
\hline $\operatorname{Mg}\left(\mathrm{cmol}_{\mathrm{c}} \mathrm{dm}^{3}\right)$ & 1.63 & 5.22 & 1.47 & 5.31 & 1.61 & 5.09 & 1.53 & 4.60 \\
\hline $\mathrm{Al}\left(\mathrm{cmol}_{\mathrm{c}} \mathrm{dm}^{3}\right)$ & 0.48 & 0.00 & 0.28 & 0.00 & 0.26 & 0.08 & 0.28 & 0.00 \\
\hline $\mathrm{H}+\mathrm{Al}\left(\mathrm{cmol}_{\mathrm{c}} \mathrm{dm}^{3}\right)$ & 3.01 & 2.90 & 2.88 & 2.91 & 2.54 & 2.86 & 2.50 & 2.74 \\
\hline $\mathrm{SB}\left(\mathrm{cmol}_{\mathrm{c}} \mathrm{dm}^{3}\right)$ & 4.80 & 15.91 & 4.27 & 16.39 & 4.74 & 15.73 & 4.53 & 13.19 \\
\hline $\mathrm{CEC}\left(\mathrm{cmol}_{\mathrm{c}} \mathrm{dm}^{3}\right)$ & 7.82 & 18.81 & 7.15 & 19.30 & 7.28 & 18.59 & 7.02 & 15.94 \\
\hline Saturation (V \%) & 61.49 & 84.55 & 59.69 & 84.86 & 65.11 & 84.53 & 63.86 & 82.65 \\
\hline Organic matter (\%) & 0.64 & 7.58 & 0.96 & 6.65 & 0.61 & 6.92 & 0.93 & 5.31 \\
\hline
\end{tabular}

$\mathrm{S} 1=100 \%$ Dystroferric Red Latosol (DRL); S2= DRL + Tropstrato $^{\circledast}(1: 1, \mathrm{v} / \mathrm{v})$. 


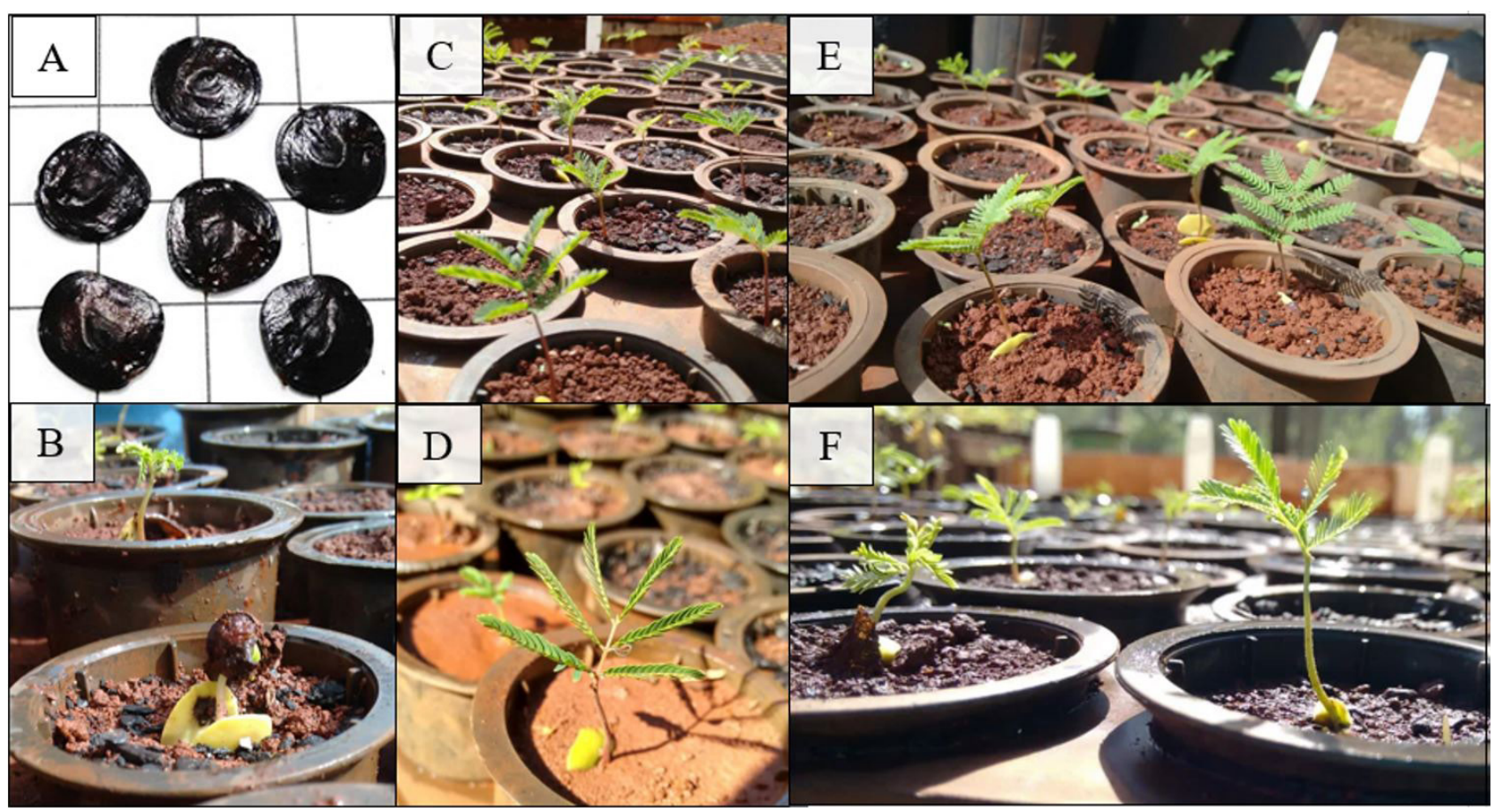

Figure 1. Seeds (A), seedlings emergence (B) and seedlings formation (C, D, E and F) of Anadenanthera peregrina (L.) Speg seedlings. Photos: Authors (2018).

the percentage of seedling emergence was accounted for, and the Speed Index (SE) [1] (Maguire, 1962) and Mean Emergence Time (MET) [2] (Labouriau, 1983) were calculated by using the following Equations 1, 2:

$$
S E=\Sigma(n i / t i)
$$

$M E T=\Sigma(n i * t i) / \Sigma n$

In which: ni= number of seedlings computed at first, second, third and last counts; $\mathrm{ti}=$ number of days from seeding to first, second, third and last counts; $\mathrm{n}=$ total number of seedlings that emerged.

After 20 days of seeding, when the emergence of the seedlings was stabilized (Figure 1C), the final emergence count was made and the results were expressed in \%.

\subsection{Survival, growth and production}

Every 30 days, from 60 to 150 Days After Seeding (DAS), survival evaluations (seedlings with fully expanded leaves and green coloration) were applied, as well as plant height with graded ruler were performed, considering as standard for distance measurement between the collar until the emergence inflection point of the highest leaf, and the results were expressed in $\mathrm{cm} /$ plant. It was also measured the stem diameter with a digital caliper $( \pm 1.0 \mathrm{~cm}$ above the substrate level) and the number of fully expanded leaves were counted.
In December, at 150 DAS, the seedlings were collected, washed in running water to remove impurities in sieves of $2.0 \mathrm{~mm}$ and later separated into leaves, stems, xylopodium and roots. By then, the leaf area (LA) was determined with the area integrator (LI-COR, Model 3100 LC; Nebraska, USA) and the results were expressed in $\mathrm{cm}^{2} / \mathrm{plant}$. Right after this procedure, the length of the largest root was measured ( $\mathrm{cm} /$ plant), as well as the length and diameter of the xylopodium, and the results were expressed in $\mathrm{mm} /$ plant.

Samples of the fresh vegetative organs (leaves, stem, xylopodium and root) of the seedlings were collected, and a precision scale was used to weight the plants $(0.0001 \mathrm{~g})$. To obtain the dry mass, the samples were placed in a $\mathrm{Kraft}^{\circledR}$ paper bag and kept in an oven with forced air circulation $\left(60 \pm 5^{\circ} \mathrm{C}\right)$, until constant dry mass.

\subsection{Physiological and quality index}

To estimate the LA and Dry Biomass Data, the following physiological indexes were calculated: Specific Leaf Area (SLA); Leaf Area Ratio (LAR) and Specific Leaf Mass (SLM) (Hunt, 1990). It was also calculated the Total Dry Mass (TDM), Ratio of Height to Diameter (RHD) and Aerial Part and Root Ratio (APRR), as well as the Dickson Quality Index (DQI) [3] (Dickson et al., 1960) according Equation 3:

$D Q I=T D M /(R H D+A P R R)$ 


\subsection{Statistical analysis}

Emergency indicator data were subjected to homogeneity of variance and normal distribution by the Bartlett and Shapiro-Wilk test, respectively. After that, all data were subjected to analysis of variance (ANOVA), and when significant by the F test, the means were submitted to Student's $t$ test for substrates and to Tukey's test for shading levels $(p<0.05)$. Survival and growth data, that were taken throughout the crop cycle, were analyzed in time, subdivided into plots and subjected to ANOVA and regression analysis $(p<0.05)$ using the SISVAR software (Ferreira, 2014).

\section{Results}

\subsection{Emergence indicators}

The rate of speed and MET of $A$. peregrina seedlings was influenced by the substrates $(p<0.05)$, and the highest SE and lowest MET occurred when seeding reached $100 \%$ of DRL, regardless of shading level. The end of seedlings emergence was not influenced by the factors under study progress $(p>0.05)$ (Table 2).

Table 2. Speed Index (SE), Mean Emergence Time (MET) and percentage of emergence of $A$. peregrina seedlings in different substrates and shading levels.

\begin{tabular}{lccc|}
\multicolumn{1}{c}{ Substrates } & SE & MET (days) & $\begin{array}{c}\text { Emergence } \\
(\%)\end{array}$ \\
\hline S1 & $1.75 \mathrm{a}$ & $13.57 \mathrm{~b}$ & $67.0 \mathrm{a}$ \\
S2 & $1.33 \mathrm{~b}$ & $14.20 \mathrm{a}$ & $61.0 \mathrm{a}$ \\
\hline Shading Levels & & & \\
$0 \%$ & $1.33 \mathrm{a}$ & $14.10 \mathrm{a}$ & $60.0 \mathrm{a}$ \\
\hline $30 \%$ & $1.83 \mathrm{a}$ & $13.82 \mathrm{a}$ & $65.0 \mathrm{a}$ \\
$50 \%$ & $1.50 \mathrm{a}$ & $13.94 \mathrm{a}$ & $70.0 \mathrm{a}$ \\
\hline $70 \%$ & $1.50 \mathrm{a}$ & $13.69 \mathrm{a}$ & $61.0 \mathrm{a}$ \\
\hline C.V. $(\%)$ & 31.25 & 3.89 & 26.80 \\
\hline
\end{tabular}

S1 = Dystroferric Red Latosol (DRL); S2= DRL + Tropstrato $^{\circledast}(1: 1, \mathrm{v} / \mathrm{v})$; C.V. = coefficient of variation. Averages followed by equal letters in the columns do not differ by Student's $t$ test for substrates and Tukey's test for shading levels $(p>0.05)$.

\subsection{Survival, growth and production}

Seedling survival was not influenced by the factors affecting the study progress $(p>0.05)$, with an average of $65 \%$. Seedling height was influenced by the triple interaction, with higher values $(9.5 \mathrm{~cm})$ under $70 \%$ shading in DRL (Figure 2a) and direct sunlight $(9.0 \mathrm{~cm})$ in DRL + Tropstrato $^{\circledR}$ (Figure $2 \mathrm{~b}$ ), both data at 150 DAS. The stem diameter was not influenced by any of the factors under study $(p>0.05)$, with an overall average of $1.19 \mathrm{~mm}$.
The RHD was influenced by the factors, days after seeding, shading (Figure 3a) and substrates (Figure 3b), and the highest values occurred in seedlings exposed to direct sunlight, followed by those under $70 \%$ shade, both at 150 DAS. In the interaction days after seeding and substrate, the highest value of the RHD (5.5) was observed in the DRL.

The number of leaves was influenced by the interaction of shading and days after sowing, verifying that under all shading levels the data fit the quadratic model. The largest amount of leaves (4.8 leaves/plant) occurred in seedlings under direct sunlight, throughout the evaluation cycle up to 145 DAS (Figure 4).

The leaf area was influenced by substrates and shading levels isolation, with the highest values occurring in DRL and in direct sunlight (Table 3). Root length was higher in seedlings produced under $50 \%$ and $70 \%$ of shade, regardless of substrates (Table 3). The Xylopodium Length (XL) was influenced by substrates and shading levels separately, with higher value in DRL and under direct sunlight (0\%). For the Xylopodium Diameter (XD), it was observed higher value in seedlings in DRL, regardless of the shading level.

Regarding the fresh mass of the leaf, it was verified that this characteristic was influenced only by the shades with higher value in direct sunlight. Therefore, for stem fresh mass there

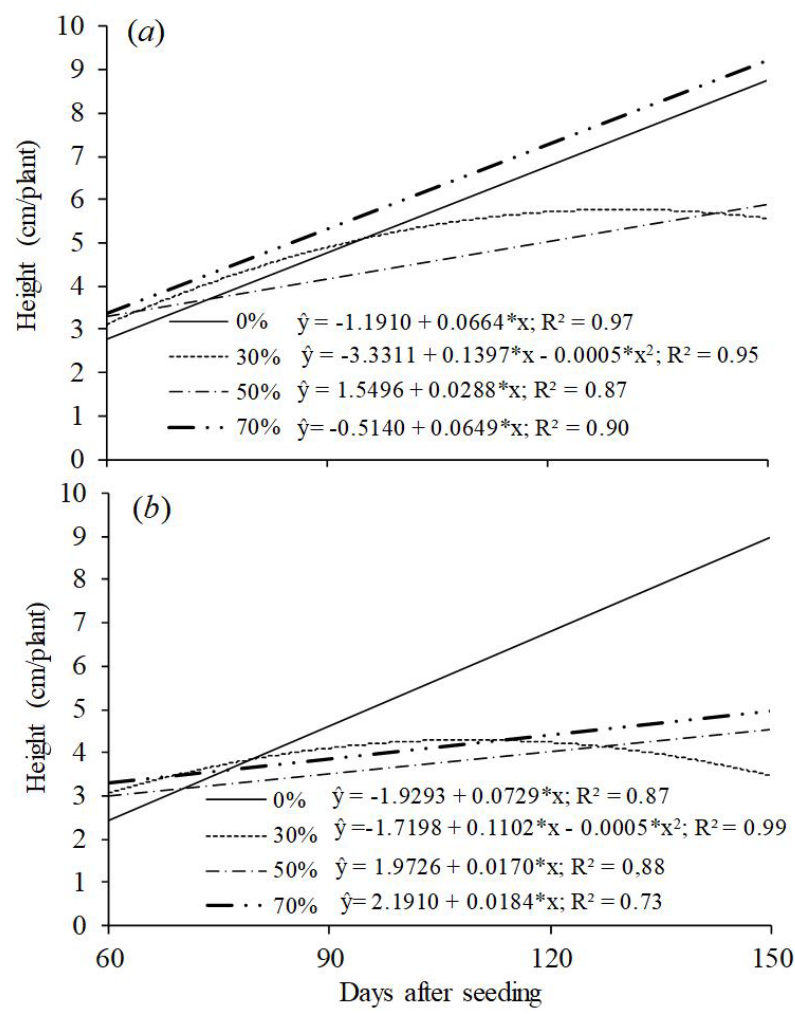

Figure 2. Height of $A$. peregrina seedlings under different shading levels and substrates at 150 days after seeding. (a): 100\% Dystroferric Red Latosol (DRL) and $(b)$ : DRL + Tropstrato ${ }^{\circledR}$ $(1: 1, \mathrm{v} / \mathrm{v}){ }^{*}(p<0.05)$. 

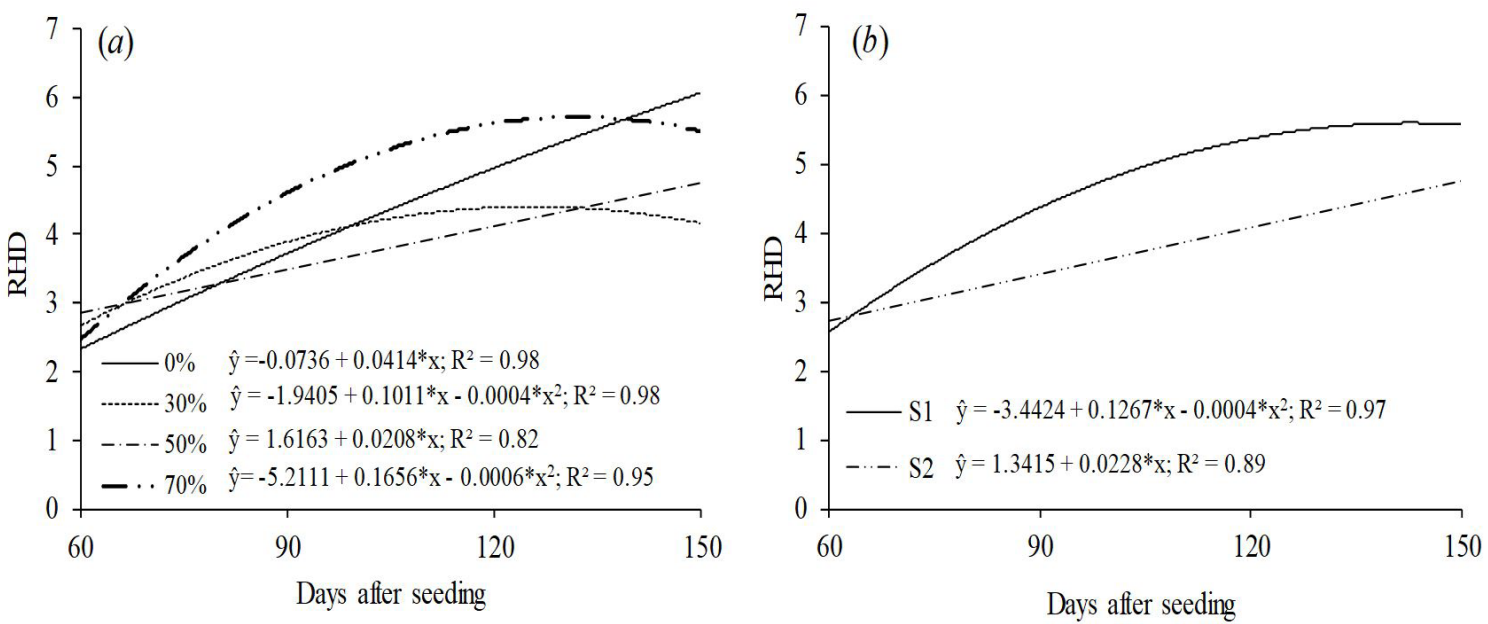

Figure 3. Ratio of Height to Diameter (RHD) of A. peregrina seedlings under different shading levels $(a)$ and substrates $(b)$, at 150 days after seeding. ${ }^{\star}(p<0.05)$.

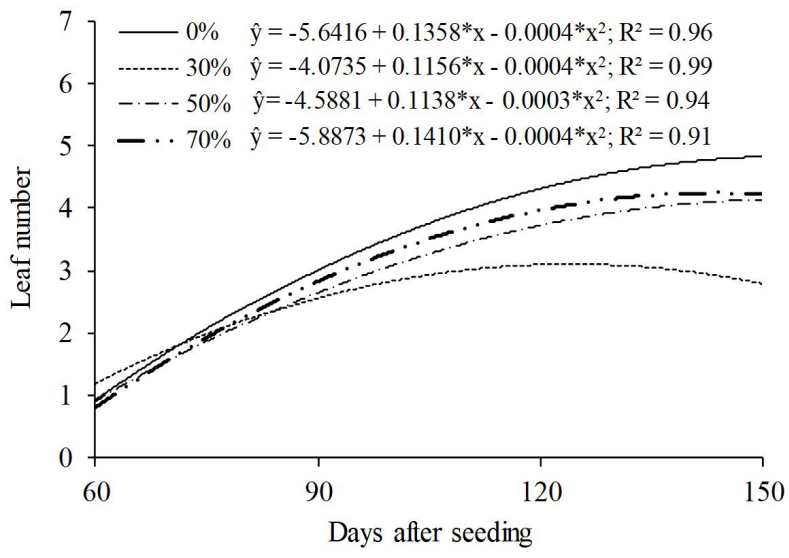

Figure 4. Leaf number of $A$. peregrina seedlings under different shading levels at 150 days after seeding. ${ }^{*}(p<0.05)$.

was a significant difference only for substrates, with higher values in DRL (Table 4). It was found that for the xylopodium and root fresh mass, there were significant differences for both substrate and shading separately, and the highest values occurred in DRL and under direct sunlight (0\%).

The leaf dry mass was influenced only by the shading levels, and its highest yield occurred in seedlings under direct sunlight (Table 5). However, the stem dry mass was not influenced by any of the factors under study $(p>0.05)$. The xylopodium dry mass presented significant difference, both as a function of substrates and shading levels, in isolation, with higher yield when produced in DRL and under direct sunlight.

\subsection{Physiological and quality index}

Only the shading levels influenced the LAR and SLA; the highest values of both characteristics occurred in seedlings under direct sunlight (Table 6). The LAR was not influenced by any
Table 3. Leaf Area (LA), Root Length (RL), Xylopodium Length (XL) and Xylopodium Diameter (XD) in A. peregrina seedlings in different substrates and shading levels.

\begin{tabular}{|c|c|c|c|c|}
\hline \multirow{2}{*}{ Substrates } & LA & $\mathbf{R L}$ & $\mathbf{X L}$ & XD \\
\hline & ( $\mathrm{cm}^{2} /$ plant $)$ & (cm/plant) & \multicolumn{2}{|c|}{ (mm/plant) } \\
\hline S1 & $47.06 \mathrm{a}$ & $14.02 \mathrm{a}$ & $46.74 \mathrm{a}$ & $4.14 \mathrm{a}$ \\
\hline S2 & $36.10 \mathrm{~b}$ & $14.46 \mathrm{a}$ & $34.67 \mathrm{~b}$ & $3.00 \mathrm{~b}$ \\
\hline \multicolumn{5}{|c|}{ Shading Levels } \\
\hline $0 \%$ & $105.50 \mathrm{a}$ & $13.08 \mathrm{~b}$ & $59.60 \mathrm{a}$ & $3.28 \mathrm{a}$ \\
\hline $30 \%$ & $16.75 \mathrm{~b}$ & $13.34 \mathrm{~b}$ & $44.94 \mathrm{~b}$ & $3.33 \mathrm{a}$ \\
\hline $50 \%$ & $22.84 \mathrm{~b}$ & $15.23 \mathrm{a}$ & $29.34 \mathrm{c}$ & $3.83 \mathrm{a}$ \\
\hline $70 \%$ & $21.25 \mathrm{~b}$ & $15.30 \mathrm{a}$ & $28.94 \mathrm{c}$ & $3.85 \mathrm{a}$ \\
\hline C.V. (\%) & 16.71 & 7.65 & 12.68 & 14.22 \\
\hline
\end{tabular}

S1 $=100 \%$ Dystroferric Red Latosol (DRL); S2= DRL + Tropstrato ${ }^{\circ}(1: 1$, $\mathrm{v} / \mathrm{v}) ; \mathrm{C} . \mathrm{V}$. = coefficient of variation. Averages followed by equal letters in the columns do not differ by Student's $t$ test for substrates and Tukey's test for shading levels $(p>0.05)$.

of the factors under study $(p>0.05)$. The ratio between APRR was influenced by the factors that were analyzed separately, being higher in seedlings produced in DRL + Tropstrato $^{\circledR}$ and direct sunlight environment. The DQI presented highest values occurred in seedlings under direct sunlight and DRL.

\section{Discussion}

\subsection{Emergence indicators}

The results obtained from SE and MET are due to the larger contact surface between the seed and the substrate, since this is one of the factors that directly affect the water absorption by the seed during the germination process (Carvalho \& Nakagawa, 2000). The soil used in the experiment was the DRL with clay texture, which presents high particle density (Santos et al., 2018), that facilitates the contact of the seed with the soil, favoring root imbibition and protrusion. 
Table 4. Leaves Fresh Mass (LFM), Stems Fresh Mass (SFM), Xylopodium Fresh Mass (XFM) and Roots Fresh Mass (RFM) in A. peregrina seedlings in different substrates and shading levels.

\begin{tabular}{|ccccc|}
\hline \multirow{2}{*}{ Substrates } & LFM & SFM & XFM & RFM \\
\cline { 2 - 5 } & & & (g/plant) & \\
\hline S1 & $1.824 \mathrm{a}$ & $0.668 \mathrm{a}$ & $2.679 \mathrm{a}$ & $0.742 \mathrm{a}$ \\
\hline Shading Levels & $1.131 \mathrm{a}$ & $0.379 \mathrm{~b}$ & $1.296 \mathrm{~b}$ & $0.394 \mathrm{~b}$ \\
\hline $0 \%$ & & & & \\
\hline $30 \%$ & $3.588 \mathrm{a}$ & $0.793 \mathrm{a}$ & $1.811 \mathrm{a}$ & $0.737 \mathrm{a}$ \\
\hline $50 \%$ & $0.610 \mathrm{~b}$ & $0.548 \mathrm{a}$ & $1.993 \mathrm{~b}$ & $0.544 \mathrm{ab}$ \\
\hline $70 \%$ & $0.944 \mathrm{~b}$ & $0.384 \mathrm{a}$ & $1.286 \mathrm{~b}$ & $0.629 \mathrm{ab}$ \\
\hline C.V. (\%) & $0.770 \mathrm{~b}$ & $0.368 \mathrm{a}$ & 46.44 & $0.361 \mathrm{~b}$ \\
\hline
\end{tabular}

$\mathrm{S} 1=100 \%$ Dystroferric Red Latosol (DRL); S2= DRL + Tropstrato ${ }^{\circledast}(1: 1, \mathrm{v} / \mathrm{v}) ; \mathrm{C} . \mathrm{V} .=$ coefficient of variation. Averages followed by equal letters in the columns do not differ by Student's $t$ test for substrates and Tukey's test for shading levels $(p>0.05)$.

Table 5. Leaves Dry Mass (LDM), Stems Dry Mass (SDM), Xylopodium Dry Mass (XDM), Root Dry Mass (RDM) and Total Dry Mass (TDM) in A. peregrina seedlings in different substrates and shading levels.

\begin{tabular}{|c|c|c|c|c|c|}
\hline \multirow{2}{*}{ Substrates } & LDM & SDM & XDM & RDM & TDM \\
\hline & \multicolumn{5}{|c|}{ (g/plant) } \\
\hline S1 & $0.942 \mathrm{a}$ & $0.257 \mathrm{a}$ & $1.190 \mathrm{a}$ & $0.459 \mathrm{a}$ & $2.919 \mathrm{a}$ \\
\hline S2 & $0.599 \mathrm{a}$ & $0.193 \mathrm{a}$ & $0.556 \mathrm{~b}$ & $0.290 \mathrm{~b}$ & $1.640 \mathrm{~b}$ \\
\hline \multicolumn{6}{|c|}{ Shading Levels } \\
\hline $0 \%$ & $1.948 \mathrm{a}$ & $0.347 \mathrm{a}$ & $1.238 \mathrm{a}$ & $0.411 \mathrm{a}$ & $4.083 \mathrm{a}$ \\
\hline $30 \%$ & $0.307 \mathrm{~b}$ & $0.183 \mathrm{a}$ & $0.884 \mathrm{ab}$ & $0.398 \mathrm{a}$ & $1.773 \mathrm{~b}$ \\
\hline $50 \%$ & $0.465 \mathrm{~b}$ & $0.200 \mathrm{a}$ & $0.876 \mathrm{ab}$ & $0.444 \mathrm{a}$ & $1.986 \mathrm{~b}$ \\
\hline $70 \%$ & $0.362 \mathrm{~b}$ & $0.170 \mathrm{a}$ & $0.493 \mathrm{~b}$ & $0.247 \mathrm{a}$ & $1.274 \mathrm{~b}$ \\
\hline C.V. (\%) & 45.82 & 57.19 & 35.41 & 47.85 & 41.61 \\
\hline
\end{tabular}

$\mathrm{S} 1=100 \%$ Dystroferric Red Latosol (DRL); S2= DRL + Tropstrato $^{\circledast}(1: 1, \mathrm{v} / \mathrm{v}) ; \mathrm{C} . \mathrm{V} .=$ coefficient of variation. Averages followed by equal letters in the columns do not differ by Student's $t$ test for substrates and Tukey's test for shading levels $(p>0.05)$.

Table 6. Specific Leaf Area (SLA) and Specific Leaf Mass (SLM), Leaf Area Ratio (LAR), Aerial Part and Root Ratio (APRR) and Dickson Quality Index (DQI) in A. peregrina seedlings in different substrates and shading levels.

\begin{tabular}{|c|c|c|c|c|c|}
\hline \multirow{2}{*}{ Substrates } & SLA & SLM & LAR & APRR & DQI \\
\hline & \multicolumn{2}{|c|}{$\left(\mathrm{g} \mathrm{cm}^{-2}\right)$} & \multicolumn{3}{|l|}{$\left(\mathrm{cm}^{2} \mathrm{~g}^{-1}\right)$} \\
\hline S1 & $14.82 \mathrm{a}$ & $0.278 \mathrm{a}$ & $53.15 \mathrm{a}$ & $0.661 \mathrm{~b}$ & $0.49 \mathrm{a}$ \\
\hline S2 & $21.69 \mathrm{a}$ & $0.306 \mathrm{a}$ & $70.18 \mathrm{a}$ & $0.861 \mathrm{a}$ & $0.29 \mathrm{~b}$ \\
\hline \multicolumn{6}{|c|}{ Shading Levels } \\
\hline $0 \%$ & $32.01 \mathrm{a}$ & $0.457 \mathrm{a}$ & $51.61 \mathrm{a}$ & $1.299 \mathrm{a}$ & $0.54 \mathrm{a}$ \\
\hline $30 \%$ & $9.72 \mathrm{~b}$ & $0.174 \mathrm{c}$ & $55.54 \mathrm{a}$ & $0.389 \mathrm{c}$ & $0.39 \mathrm{ab}$ \\
\hline $50 \%$ & $13.09 \mathrm{~b}$ & $0.250 \mathrm{bc}$ & $63.15 \mathrm{a}$ & $0.576 \mathrm{~b}$ & $0.39 \mathrm{ab}$ \\
\hline $70 \%$ & $18.20 \mathrm{~b}$ & $0.288 \mathrm{~b}$ & $76.36 \mathrm{a}$ & $0.781 \mathrm{ab}$ & $0.25 \mathrm{~b}$ \\
\hline C.V. (\%) & 43.17 & 16.17 & 49.95 & 26.25 & 38.81 \\
\hline
\end{tabular}

$\mathrm{S} 1=100 \%$ Dystroferric Red Latosol (DRL); S2= DRL + Tropstrato ${ }^{\circledast}(1: 1, \mathrm{v} / \mathrm{v}) ; \mathrm{C} . \mathrm{V} .=$ coefficient of variation. Averages followed by equal letters in the columns do not differ by Student's $t$ test for substrates and Tukey's test for shading levels $(p>0.05)$.

The emergence percentage of seedlings did not influence this process, possibly because it is a native species delimited in this itself phytophysiognomy, thus it has the ability to adapt to the edaphic conditions of Cerrado (Gross et al., 2004). However, it should be noted that emergence and speed responses may vary among Cerrado species, mainly due to their successional and ecological characteristics. In addition, the information regarding the ecophysiology of germination and emergence of native tree species is still scarce, making our study necessary for the elaboration of plans and monitoring of the environmental recovery.

\subsection{Survival, growth and production}

The species were not influenced by the factors under study for seedling survival, thus indicating ecological amplitude at different light gradients and soil fertility conditions. The height under direct sunlight in this study was characterized by being 
present in open areas, where there is a high light incidence, especially in the early development phase (Souza et al., 2012).

Nevertheless, plant growth depends on its degree of adaptability to the type of environment (Souza et al., 2019). The height of the plant is one of the variables to indicate its development when subjected to different shading conditions, as some species show excessive etiolation when they were able to grow under high shade level, however, not being an advantage since the seedling may reach the soil under field conditions.

The RHD indicates the robustness of the seedlings that will be taken to the field, as a balanced development is expected (Campos \& Uchida, 2002; Freitas et al., 2012), both in height and diameter. Values for $A$. peregrina seedlings did not show the presence of etiolation, demonstrating balanced distribution of receiving photoassimilates. The increase of the number of leaves is important because it indicates an increase in photosynthesis/area, which suggests its efficiency in the production of photoassimilates that are later translocated to other parts of the plant, that can be favored by the input of phytomass (Martins et al., 2015), since a plant that has a well-developed aerial stem improves its ability to intercept and use the Photosynthetically Active Radiation (PAR) under direct sunlight.

On the other hand, some species have the ability to be adapted to shaded environments due to early or late secondary successional species (ecological group), and in some cases owing to their phenotypic plasticity. This information is important because it facilitates planning and making decision for choosing the area to transplant the seedlings, ensuring the success of reforestation, enrichment of forests or formation of integrated production systems. The increase in leaf area due to the higher amount of leaf lamina at the same light condition (Figure 4) that favors the input of the biomass may be directly related to the photosynthetic capacity $\left(A_{\max }\right)$ of the plant, thus, the higher the value is taken the larger the unit of PAR to capture solar radiation will be.

Low water loss in seedlings under $50 \%$ and $70 \%$ of shading favored the elongation of the root system and its exploitation in the soil (Oliveira et al., 2018), the moisture was longer kept, due to lower evaporation substrate, which favored its development, in the seedlings with smaller XL. However, it should be noted that even with smaller roots under $0 \%$ and $30 \%$ of shading levels, there was an increase in the morphometric aspects of reserve structures, which contributes to their ecological tolerance to environmental conditions.

The increase of xylopodium is important especially in environment under high irradiance because this reserve may assist plants to overcome environmental restrictions, such as seasonal drought and fire, owing to the prominent presence of buds in the upper portion and photoassimilates depended on reserve organ by favoring the capacity of ecological resistance, as it has the potential for sprouting (Ratter et al., 1997; Cruz et al.,
2016) and ensuring the survival and establishment of seedlings. These same authors described that for the development of these structures, there is generally a higher nutritional demand.

However, this study demonstrated that $A$. peregrina seedling production may be adapted to low and medium soil fertility conditions, even for the formation of different vegetative organs, since the species has the potential to be inserted in areas from medium to high levels of degradation, that are characterized by low Vegetation Indices (VI), soil nutrient and organic matter, especially consisted of the presence of acid $\mathrm{pH}$ and aluminum (Table 1). However, the highest growth indicators of xylopodium, especially length, contribute to the ability of A. peregrina seedlings to enhance water and nutrient storage.

This increase of leaves fresh mass was associated with the fact that the seedlings present larger number of leaves (Figure 4) and LA (Table 3) at the same light condition. Predominantly, the species $A$. peregrina develops well in soils with low fertility and organic matter, typical of tropical regions, such as the Cerrado biome, contributing to its ecological tolerance. However, the substrate preference may vary between species. The seedlings of the Cerrado species called Hymenaea stigonocarpa Mart. responded positively to substrates that were rich in organic matter and nutrients (Mizobata et al., 2016), being different from the results observed for $A$. peregrina.

Possibly, the result of xylopodium and root fresh as well as dry mass was associated with the higher amount of the PAR, favoring the photoassimilates and biomass productions. Similarly, regarding the root mass, a study by Larraburu et al. (2018) showed that both the fresh and dry mass of the roots from the Cerrado species called Handroanthus ochraceus (Cham.) Matos were influenced by luminosity, and those that were exposed to higher irradiance levels $(0 \%)$ presented higher mass production. Thus, prominent results regarding leaf dry mass in direct sunlight may have occurred because the plant obtained higher concentration of photoassimilates and irradiation adaptation when compared to shading levels (Ajalla et al., 2012).

The mass input is due to the largest indicators of this reserve structure, being related to its length and diameter (Table 3) under these same seedling production conditions. Seeing that the species $A$. peregrina presented relevant production performance in direct sunlight environments, it may be possible to reduce the acclimatization (rustification) of these seedlings, since they are already adapted to these natural light conditions.

\subsection{Physiological and quality index}

The increase of SLA and SLM components, under direct sunlight due to the functional adaptive capacity of the leaf tissues, represents the increase of the palisade layer and biomass accumulation, directly related to the need for the plant to 
grow in high irradiance environments (Martins et al., 2015), favoring its ecological tolerance.

The high values of DQI may be associated with their higher growth characteristics, physiological indices and yield in these same conditions. Reis et al. (2016) highlighted that some characteristics were evaluated separately, for instance, the height when this parameter does not ensure neither the quality of the seedling nor its survival under field conditions, especially by using the technique of etiolation. This way, the DQI considers the level of robustness and biomass input, and when the higher the value is taken, the greater its possibility of survival and establishment in the field after transplanting will be, nevertheless, also being an indicator of seedlings pattern evaluation, especially of forest essences.

In a general way, the species $A$. peregrina was adapted to high light conditions and from low to medium soil fertility conditions, typical aspects of the Cerrado biome, with the presence of acid $\mathrm{pH}(5.0)$ and aluminum. The seedlings of this species may be inserted in degraded areas and/or integrated in sustainable production systems, both at the edges or open areas, being indicated as a heliophilous species, in other words, this species grows under shading conditions in which there is a reduction of leaf aspects and seedling quality.

\section{Conclusion}

Anadenanthera peregrina (L.) Speg seedlings presented morphophysiological characteristics that provided high capacity for ecological tolerance under high irradiance environmental and soils with low to medium nutrient inputs and Soil Organic Matter (SOM) pools.

The indicators of seedling emergence were more viable with seedling growth in $100 \%$ of DRL, regardless of shading levels. The production of $A$. peregrina in $100 \%$ of DRL and under direct sunlight provided higher seedlings quality standards.

\section{Acknowledgements}

The authors thank the Foundation for the Development of Education, Science, and Technology of the State of Mato Grosso do Sul (FUNDECT) and the Coordination for the Improvement of Higher Education Personnel (CAPES) for the financial support associated with the development and dissemination of this work, and the National Council for Scientific and Technological Development (CNPq) for the research scholarship

\section{Submission status}

Received: 27 Nov., 2019

Accepted: 28 Apr., 2020

Associated Editor: Eduardo Vinicius da Silva

\section{Correspondence to \\ Cleberton Correia Santos}

Universidade Federal da Grande Dourados (UFGD), Faculdade de Ciências Agrárias (FCA)

Rodovia Dourados-Itahum, Km 12, CEP 79825-070, Dourados, MS, Brasil

e-mail: cleber_frs@yahoo.com.br

\section{Financial support}

Foundation for the Development of Education, Science, and Technology of the State of Mato Grosso do Sul (Grant/Award Number: 59/300.029/2015).

\section{References}

Ajalla ACA, Volpe E, Vieira MC, Heredia Zárate NA. Production of baru (Dipteryx alata Vog.) seedlings under three levels of shading and four textural classes of soil. Revista Brasileira de Fruticultura 2012; 34(3): 888-896. http://dx.doi.org/10.1590/S0100-29452012000300031.

Bonamigo T, Scalon SPQ, Pereira ZV. Substrato e níveis de sombreamento no crescimento inicial de mudas de Tocoyena formosa (Cham. \& Schltdl.) K. Schum. (Rubiaceae). Ciência Florestal 2016; 26(2): 501-511. http://dx.doi.org/10.5902/1980509822750.

Campos MAA, Uchida T. Influence of shade on the growth of seedlings of three Amazon species. Pesquisa Agropecuária Brasileira 2002; 37(3): 281-288. http://dx.doi.org/10.1590/S0100-204X2002000300008.

Carlos L, Venturin N, Venturin RP, Alves JM, Silva PO. Liming and phosphating in Dalbergia nigra (Vell.) Allemão ex Benth. seedlings. Floresta e Ambiente 2018; 25(4): 1-10. http://dx.doi. org/10.1590/2179-8087.023917.

Carvalho NM, Nakagawa J. Sementes: ciência, tecnologia e produção. 4. ed. Jaboticabal: FUNEP; 2000.

Carvalho SD, Castilho JA. Influence of light on plant-phyllosphere interaction. Frontiers in plant science 2018; 9(1482): 1-16. http:// dx.doi.org/10.3389/fpls.2018.01482. PMid:30369938.

Ceccagno H, Dutra-de Souza PV, Schafer G, Demari-Avrella E, Sidnei-Fior C, Schwarz SF. Potential of Pinus sp. needles for use as substrate conditioners in the production of 'Trifoliata' rootstock in greenhouses. Chapingo Serie Horticultura 2019; 25(1): 5-16. http:// dx.doi.org/10.5154/r.rchsh.2018.02.003.

Cruz FRS, Andrade LA, Feitosa RC. Seedlings production of umbuzeiro (Sponduias tuberosa Arruda Cãmara) in diferente substrates and size of bags. Ciência Florestal 2016; 26: 69-80. http:// dx.doi.org/10.5902/1980509821092.

Dickson A, Leaf AL, Hosner JF. Quality appraisal of white spruce and white pine seedling stock in nurseries. Forestry Chronicle 1960; 36(1): 10-13. http://dx.doi.org/10.5558/tfc36010-1.

Dornelles P, Silva FG, Freiberger MB, Severiano EC, Tavares GG. Initial development and nutrition of Eugenia dysenterica DC. on substrates formulated with sugarcane bagasse and filter cake. Australian Journal of Crop Science 2018; 12(9): 1459-1464. http:// dx.doi.org/10.21475/ajcs.18.12.09.PNE1133. 
Ferreira DF. Sisvar: a guide for its bootstrap procedures in multiple comparisons. Ciência e Agrotecnologia 2014; 38(2): 109-112. http:// dx.doi.org/10.1590/S1413-70542014000200001.

Fonseca FA, Scotti MR. Growth and root responses of woody species to rocky substrate: implications for gully rehabilitation. Plant Biosystems 2018; 152(5): 918-928. http://dx.doi.org/10.1080 /11263504.2017.1376721.

Freitas GA, Melo A, Pereira MAP, Andrade CAO, Lucena N, Silva RR. Influência do sombreamento na qualidade de mudas de Sclerolobium paniculatum Vogel para recuperação de área degradada. Journal of Biotechnology and Biodiversity 2012; 3(3): 5-12. http:// dx.doi.org/10.20873/jbb.uft.cemaf.v3n3.freitas.

Gross E, Cordeiro L, Caetano FH. Nodulation and mycorrhizal infection in Anadenanthera peregrina var. falcata on autoclaved and non-autoclaved Cerrado soil. Revista Brasileira de Ciência do Solo 2004; 28(1): 95-101. http://dx.doi.org/10.1590/S010006832004000100010 .

Hunt R. Basic growth analysis: plant growth analysis for beginners. London: Unwin Hyman, 1990, 112p. http://dx.doi.org/10.1007/97894-010-9117-6.

Labouriau LG. A germinação das sementes. Washington: Secretaria Geral da Organização dos Estados Americanos; 1983. 174 p.

Larraburu EE, Correa GS, Llorente BE. In vitro development of yellow lapacho (Bignoniaceae) using high-power light emitting diode. Revista Árvore 2018; 42(5): 1-12. http://dx.doi.org/10.1590/180690882018000500008 .

Maguire JD. Speed of germination-aid in selection and evaluation for seedlings emergence and vigor. Crop Science 1962; 1(2): 176-177. http://dx.doi.org/10.2135/cropsci1962.0011183X000200020033x.

Martins ACF, Schiavini I, Araújo GM, Lopes SF. Adaptative capacity of Cerrado's species used in enviromental recovery areas. Revista Árvore 2015; 39(3): 543-550. http://dx.doi.org/10.1590/010067622015000300015 .

Mizobata KKGS, Santos CM, Maltoni KL, Faria GA, Cassiolato AMR. Growth of Hymenaea stigonocarpa as a function of the addition of residues in degraded soil. Revista Brasileira de Engenharia Agrícola e Ambiental 2016; 20(3): 223-229. http://dx.doi.org/10.1590/18071929/agriambi.v20n3p223-229.

Monteiro JM, Albuquerque UP, Lins-Neto EM, Araújo EL, de Amorim EL. Use patterns and knowledge of medicinal species among two rural communities in Brazil's semi-arid northeastern region. Journal of Ethnopharmacology 2006; 105(1-2): 173-186. http://dx.doi.org/10.1016/j.jep.2005.10.016. PMid:16298502.

Mori CLSO, Mori FA, Mendes LM, Silva JRM. Caracterização da madeira de angico-vermelho (Anadenanthera peregrina (Benth) Speg) para confecção de móveis. Brasil Florestal 2003; 22(77): 29-36.

Mota GS, Sartori CJ, Miranda I, Quilhó T, Mori FA, Pereira H. Bark anatomy, chemical composition and ethanol-water extract composition of Anadenanthera peregrina and Anadenanthera colubrine. PLoS One 2017a; 12(12): 1-14. http://dx.doi.org/10.1371/ journal.pone.0189263. PMid:29281656.

Mota LHS, Scalon SPQ, Heinz R, Dresch DM. Substrates and water availability on the emergence and initial growth of Alibertia sessilis
Schum. seedlings. Floresta 2017b; 47(4): 513-522. http://dx.doi. org/10.5380/rf.v47i4.53083.

Oliveira FA, Alves RC, Bezerra FMS, Lima LA, Medeiros AS, Silva NKC. Heterogeneous salinity in the root system of bell pepper in greenhouse. Revista Brasileira de Engenharia Agrícola e Ambiental 2018; 22(8): 519-524. http://dx.doi.org/10.1590/1807-1929/agriambi. v22n8p519-524.

Pinheiro MHO, Monteiro R. Contribution to the discussions on the origin of the Cerrado biome: brazilian savanna. Brazilian Journal of Biology = Revista Brasileira de Biologia 2010; 70(1): 95-102. http:// dx.doi.org/10.1590/S1519-69842010000100013. PMid:20231964.

Ratter JA, Ribeiro JF, Bridgewater S. The Brazilian Cerrado vegetation and threats to its biodiversity. Annals of Botany 1997; 80(3): 223230. http://dx.doi.org/10.1006/anbo.1997.0469.

Reis SM, Marimon-Júnior BH, Morandi PS, Santos CO, Oliveira B, Marimon BS. Initial development and quality of saplings of Copaifera langsdorffii Desf. Under different levels of shading. Ciência Florestal 2016; 26(1): 11-20. http://dx.doi.org/10.5902/1980509821061.

Ruban AV. Evolution under the sun: optimizing light harvesting in photosynthesis. Journal of Experimental Botany 2015; 66(1): 7-23. http://dx.doi.org/10.1093/jxb/eru400. PMid:25336689.

Santos HG, Jacomine PKT, Anjos LHC, Oliveira VA, Lumbreras JF, Coelho MR et al. Sistema brasileiro de classificação de solos. 5. ed. Rio de Janeiro: Embrapa Solos; 2018. 356 p.

Scheer MB, Carneiro C, Bressan AO, Santos KG. Production of Anadenanthera colubrina (Vell.) Brenan seedlings using substrates based on composted sewage sludge. Cerne 2012; 18(4): 613-622. http://dx.doi.org/10.1590/S0104-77602012000400011.

Silva FC. Manual de análises químicas do solo, plantas e fertilizantes. 2. ed. Brasília: Embrapa Informação Tecnológica; 2009. 627p.

Souza CC, Oliveira FA, Silva IF, Amorin MS No. Avaliação de métodos de determinação de água disponível e manejo da irrigação em terra roxa sob cultivo de algodoeiro herbáceo. Revista Brasileira de Engenharia Agrícola e Ambiental 2000; 4(3): 338-342. http:// dx.doi.org/10.1590/S1415-43662000000300006.

Souza JC, Pedrozo CÂ, Silva KD, Oliveira VXA, Alencar AMS. Environments for seedlings production and nodulation by rhizobia in Tachigali vulgaris. Ciência Florestal 2019; 29(1): 116-129. http:// dx.doi.org/10.5902/1980509827955.

Souza MF, Martins ER, Fernandes LA, Nere OS. Emergência e desenvolvimento inicial de sementes de Dimorphandra mollis Benth. em campo. Revista Brasileira de Plantas Medicinais 2016; 18(1): 186-190. http://dx.doi.org/10.1590/1983-084X/15_066.

Souza PB, Souza AL, Costa WS, Peloso RVD, Lana JM. Floristic and diversity of tree species and shrub under a stand of Anadenanthera peregrina (L.) Speg. Cerne 2012; 18(3): 413-421. http://dx.doi. org/10.1590/S0104-77602012000300008.

Uliana MB, Fey R, Malavasi MM, Malavasi UC. Seedling production of Anadenanthera macrocarpa as a function of substrates and fertigation regimes. Floresta 2014; 44(2): 303-312. http://dx.doi. org/10.5380/rf.v44i2.31412. 